\title{
The Birrinydji Legacy: Aborigines, Macassans and mining in north-east Arnhem Land
}

\author{
Ian S. McIntosh
}

\begin{abstract}
For some clans in north-east Arnhem Land, the Dreaming-being Birrinydji is the king, boat captain and blacksmith. He is at once the minerals of the ground and the land itself, and Yolngu (Aborigines) are born in his image and ceremonially enact his will. Yet Birrinydji represents the technology and power possessed by non-Aborigines, but not Aborigines. The perception is that following the days when Indonesian fishermen from Macassar frequented the northern coast, Balanda (non-Aborigines) have become wealthy at Aboriginal expense by exploiting the resources of the Aboriginal domain. In an analysis of Aboriginal oral history and of the spirit-being Birrinydji, I account for widely varying attitudes by Yolngu towards mining and exploration. One of the principal questions I ask is, what is the relevance of the view held by some Warramiri, Dhalwangu and Gumatj clan members that at some point in the distant past, under the tutelage of Birrinydji, Aborigines themselves were miners and they fashioned metal tools from locally occurring iron-ore outcrops?
\end{abstract}

\section{Contemporary Arnhem Land}

The geographic focus is the Aboriginal community of Galiwin'ku (Elcho Island) and also the homeland of Dholtji in Australia's Northern Territory, approximately 500 kilometres east of the regional capital of Darwin. The largest settlement in north-east Arnhem Land, Galiwin'ku was established in 1942 by the Methodist Overseas Mission. The community is home to approximately 1500 out of a total Yolngu population of 5000 . The traditional Aboriginal owners of the island share their homeland with eight other closely related clan groups, whose country lies in the immediate vicinity of the settlement. Dholtji is a small outstation to the north-east of Galiwin'ku and has a population of perhaps ten people, but only during the Dry season.

The people of north-east Arnhem Land are known as Yolngu, but they have also been referred to in the literature as Murngin ${ }^{1}$ and Wulamba. ${ }^{2}$ Dualism is the defining feature of the Yolngu universe. Each person is born into a patrimoiety, named Dhuwa or Yirritja, as well as a patrilineal land-owning clan which again is either Dhuwa or

1. Warner 1969.

2. Berndt \& Berndt 1954. 
Yirritja. Each member possesses rights to certain lands through their father, for it is the father who confers clan identity, but clan members also have interests in the land of their mother and their mother's mother. In this paper attention is focussed on the Yirritja moiety Warramiri clan, and in particular the views of the ex-leader of the clan, the late David Burrumarra M.B.E.

The traditional owners of Galiwin'ku and Dholtji are land owners in the eyes of the Australian law. Yolngu property rights came under the national spotlight in the 1960s, when Aborigines living at nearby Yirrkala took their case against the mining company Nabalco to the Supreme Court to determine who owned the land. As is well documented $^{3}$, the judgement was that while Aborigines belonged to the land, it did not belong to them. The court did not recognise community or group land interests and the decision was that Aboriginal property rights had been wiped out with the assertion of sovereignty by the British in $1788 .^{4}$ The decision of the court prompted the establishment of a commission of inquiry into granting land rights to Aborigines in the Northern Territory. This led to the enactment of the Aboriginal Land Rights Act (NT) 1976, and the formation of land councils to pursue land claims on behalf of traditional Aboriginal land owners and to act as liaison with regard to development proposals. Aborigines, who make up $25 \%$ of the Northern Territory's population, now own over $50 \%$ of its land mass. The form of title is inalienable or Aboriginal freehold. Aborigines hold title not just for themselves but for future generations. The land cannot be sold or given away.

\section{Introducing Birrinydji}

For at least 200 years, fishermen from southern Sulawesi, the Macassans ${ }^{5}$, made annual voyages to the Arnhem Land coast in search of the exotic delicacy, trepang, which they would sell to the Chinese. Yirritja moiety Warramiri clan members once had a pivotal role mediating relations with Macassans. In a process that was to be echoed elsewhere in Australia by European colonists, Macassans bestowed the title Rajah (king) on certain Aboriginal elders who would act as their brokers. In turn, these leaders would regulate trade in highly desired foreign goods with inland Aboriginal tribes. ${ }^{6}$ The last Rajah of Melville Bay and Dholtji was Ganimbirrngu ${ }^{7}$ who was the father of David Burrumarra, the immediate past Warramiri clan leader from Elcho Island. ${ }^{8}$ Dholtii was the place where Matthew Flinders encountered the Macassan fleet in $1803^{9}$ and where great festivities are described as taking place on shore as up to sixty praus and a thousand men reconnoitered prior to their return to Sulawesi. ${ }^{10}$ Following the departure of

\footnotetext{
3. Williams 1986.

4. A decision that was overturned in the Mabo 2 High Court case in 1991.

5. This is an expression used by Aborigines to refer to all foreign trepang (bêche-de-mer) fishermen. While primarily from Macassar, boat crews were drawn from many of the islands of eastern Indonesia.

6. Thomson 1949.

7. Macknight 1979.

8. McIntosh 1996a. Ratfer than bestowing the gorget upon Aborigines, Macassans offered Burrumarra's father a ceremonial mast, flag and sword.

9. Flinders 1813. Flinders named the surrounding islands after 'the venerable gentlemen' of the English East India Company.

10. Berndt \& Berndt, 1954.
} 
the Macassans in 1907 and the establishment of missions in north-east Arnhem Land in the 1920s, places such as Dholtji became all but deserted.

In 1988, eighty years after the end of the Macassan era, David Burrumarra promoted the view amongst those who would listen that mining on his land at Dholtji would help restore wealth and status to Aboriginal people-a wealth and status that had been usurped firstly by these itinerant voyagers from Sulawesi and then later by white settlers. For the aging Aboriginal leader there were no doubts. Mining was a part of Aboriginal history and it was an avenue to the good life. Since time immemorial, coastal haematite outcrops had been transformed into iron-bladed tools by Yolngu working under the guidance of the Dreaming figure Birrinydji, a being in the image the boat captain and blacksmith, known in some accounts as 'Captain Cook'. In the Gulf of Carpentaria Aborigines say that the Dreaming era came to an end with the arrival of non-Aborigines. ${ }^{11}$ In the same way, following first contact with the Macassans, northeast Arnhem Land Aborigines are said to have lost the skills and technologies of the 'new world'. ${ }^{12}$ Burrumarra sought a return to this 'golden era'.

Under provisions of the Aboriginal Land Rights Act (NT) 1976, Aborigines must respond to requests for a meeting with potential developers not less than every five years. In 1988, as with previous negotiations, Burrumarra's position remained the same, though he lacked support from many members of his clan. The destruction of sacred sites in the vicinity of the Nabalco bauxite mine at Gove was still fresh in people's minds, even twenty years on. While close family did not question Burrumarra's authority as the spokesperson for the clan or Birrinydji, some Yolngu saw him as attempting to sell off the country to Balanda for his own personal gain. Others saw his views on the past as obscure and anachronistic and they objected to mining exploration, even while acknowledging that the land in question was sacred to the memory of a 'timeless' partnership that was once deemed to have existed between Aborigines and non-Aborigines through Birrinydji. As Burrumarra said:

Birrinydji had the mind of a Balanda, but the skin was not the same. Birrinydji has brown skin but his law is for all, not just for brown and white, but black as well, and all the people of the world... Birrinydji was the king just as my father was king. My father was also a servant... When he looks in the mirror he sees Birrinydji, but also the whale and the octopus. ${ }^{13}$ The Warramiri honour all three. ${ }^{14}$

Warramiri oral history tells a tale of first contact and a history of race relations that is at odds with contemporary historical accounts of the Macassan era. This paper revolves around discussions with Burrumarra and other members of the Warramiri clan and Yirritja moiety on the history of iron-making in Aboriginal Australia. It examines the relevance of this history in the way that Aborigines in north-east Arnhem Land are responding to requests for access to their country by mining companies.

11. Trigger 1992.

12. McIntosh $1994 \mathrm{~b}$, in a parallel story, refers to how Burnumarra could fly in the days before the mission. Upon entering community life in the 1940 s, he lost this ability.

13. Warramiri totems.

14. McIntosh 1996a. 


\section{Burrumarra's dream}

In the weeks following a 'yes' decision to mining at a Northern Land Council meeting held at Galiwin'ku to discuss the possibility of exploration in the vicinity of his outstation, Burrumarra had a dream which sparked considerable discussion. In the dream Burrumarra's younger brothers were clearing land for an airstrip at Dholtji ${ }^{15}$, at this ceremonial centre for Birrinydji. In complying with Burrumarra's wish, the brothers were planning to make Dholtji the large settlement it had been both in the days of, and prior to the Macassan era.

The brothers had nearly finished the airstrip when their bulldozer was halted by an obstacle. It was a huge gold nugget. 'This must belong to Birrinydji' they thought, and went off to get their older brother. The Warramiri leader stared at the find and understood that the wealth of the white men could be theirs once again, and he reflected on the past. Birrinydji was the rich minerals of the earth, the transformed haematite, the source of the technology that made foreigners wealthy and allowed them to dominate Aborigines. He bent down to pick up the prize and, as he lifted it and held it in his arms, Birrinydji, Burrumarra's Aboriginality and his Dreaming went into the ground and out of his life. He had the wealth of the Balanda and that was all that he had. To savage the earth for its 'spirit', as in mining, was to lose one's identity and become like the Balanda. By resisting the temptation one would maintain one's Aboriginality but also one's poverty.

Dreams like this have their counterpart in recorded Yolngu mythology. In the Yirritja moiety Gupapuyngu clan there is the story of Djuranydjura, the dingo, who meets Macassans on the beach in a first contact narrative. ${ }^{16}$ The Macassans want to give the dog matches, but they are rejected for Djuranydjura uses fire sticks and has always done so. The visitors offer the dog rice to eat, but Djuranydjura is happy with his lot, there being plenty of fish in the creeks and kangaroo in the bush to meet his needs. When the Macassan offers the dog all that he has, Djuranydjura replies that if that was to be the case, then he would be the Macassan and Macassans would be Aborigines. On this note, both parties retreat to their place of origin. ${ }^{17}$

For Aborigines, the Djuranydjura narrative is both a story of defiance and of loss. On the one hand it appears as a statement of Aboriginal pride and self-sufficiency and it is told in school culture classes as such. On the other hand, as more detailed variations of the myth attest ${ }^{18}$ it is an affirmation that Aborigines were dependent on nonAborigines for the things that they came to find essential following contact with the Other, i.e. metal tools, cloth, dug-out sailing canoes and so on. For instance, in one extended version of the myth linked to a different site, Djuranydjura is a black male dog, though following contact with Macassans he becomes female and white. This change of status sanctioned both trade and sexual relations between Aborigines and

15: Dholtji is a loan word, from the Portuguese via Macassans meaning 'the gift'. Dholtji is the gift of Birrinydji to the Warramiri people.

16. McIntosh 1992; 1994a; 1996a.

17. Of note is the fact that no trepanging occurred at the site of this mythical encounter on Howard Island. Macassans regarded this site as strictly off limits. P. Lanhupuy pers. comm. 1988.

18. see McIntosh 1992; Warner 1958. 
Macassans according to Burrumarra. ${ }^{19}$ The rock that represents the Macassan who met the Dog in this variation is an 'increase site' for Yolngu at Elcho Island. Prior to fishing expeditions, Yolngu rub and sing to the rock, which is suggestive of the way Aborigines benefitted materially from trade with the visitors, (though attributing the wealth of the Other to an Aboriginal Dreaming).

In Burrumarra's Warramiri clan, the anti-social Dog Bol'lili is credited with a similar dramatic turnabout in Aboriginal fortunes. Instead of the Dog changing colour, in this narrative, at the 'beginning of time', Warramiri Aborigines were white and rich and Macassans black and poor, and Macassans worked for Aborigines. It was Bol'lili's refusal to co-operate with Macassans that led to Aboriginal loss in relation to outsiders. ${ }^{20}$ As with the Djuranydjura narrative, this is an outside story, though no known variations inspire the same sense of independence as with Djuranydjura. ${ }^{21}$ The inside version of both these encounter narratives is that of Birrinydji and it is far more harrowing. ${ }^{22}$ Both Balanda and Yolngu were once united by a single law. They lived in their own lands and, as sovereign nations, respected each other's domains. But with the coming together of peoples in history and the ensuing struggle over access to resources, Birrinydji's law emerged as the guiding principle for Yolngu in race relations. According to Burrumarra, Yolngu are 'soldiers for Birrinydji'. The belief inspires pride in one's heritage and of oneself as the owner of the land. 'Black for black and white for white' is one way a senior Yolngu referred to this inheritance. The myth also inspires resentment at Balanda for growing rich at Aboriginal expense and also dismay, for Aborigines once had this wealth and then lost it. For people such as Burrumarra, regaining wealth and control of one's land is part of Birrinydji's plan. This was the Warramiri leader's dream.

\section{Theoretical overview}

The historian Campbell Macknight has called for an analysis of the way the memory of the often turbulent indigenous experience with Macassans has been transformed by Aborigines over time and is relevant in contemporary politics. ${ }^{23} \mathrm{Keen}$ likewise has suggested a need to '...trace trajectories of transformation in relations, powers, trends, events, and the forms into which people try to shape their worlds' ${ }^{24}$ In this paper I ask, 'What is the relation between giving an account of the past and realising a future?' What happens when 'timeless' truths of the Dreaming are in conflict with prevailing or available data?

Bloch $^{25}$ referred to a distinction between systems by which we know the world in a practical sense and systems by which we accommodate history and keep the law. This was equated with Marx's distinction between ideology and knowledge. For the Warramiri there is knowledge of the Macassan past that pertains to everyday communication, (recently introduced to Arnhem Land schools is a course on Macassan history) and

19. Beckett 1993 says there is a desire to both unite with the Other and yet simultaneously to maintain a separate identity and preserve local autonomy.

20. Warner 1958.

21. Bulunha, the white male Dog, has this role.

22. see McIntosh 1996b.

23. Macknight 1972, p. 317; 1986, p. 72.

24. Keen 1994, p. 296.

25. Bloch 1977. 
there is knowledge of Macassans applicable to ritual communication amongst elders in a ceremonial setting (e.g. Birrinydji comes from the land of the Warramiri and drew all outsiders to Arnhem Land by the strength of his marr or desire). 'Outside' (or public) and 'inside' (sacred or esoteric) are apt labels for the distinction. According to Bloch, anthropological analysis must take into account the changing meaning of the past in the present. Answers to questions such as: what is known about Macassans, what is possible to know, and who has the right to speak on this subject, reflect the interaction of emic and etic perspectives. The ancestral being Birrinydji is constituted in the everchanging relations between Aborigines and others, and Yolngu decision making with regard to mining reflects the ever-changing understanding of this Dreaming.

In the 1960s, Warramiri Yolngu worked with historians charting Macassan sites along the coast. The subject of Birrinydji was not raised, and one of the reasons was that 'inside' truths and available or prevailing 'outside' data did not address the same questions, and some Yolngu wanted to keep it that way. ${ }^{26}$ For Burrumarra, only the Birrinydji narrative was seen to provide answers to questions such as: What brought the Macassans to Arnhem Land? Why do some Aboriginal Dreamings refer to ancestral figures in the image of the Macassan? Why have some Yolngu a ceremony for iron and not others? Burrumarra did not know that in the 1700s, Sama Bajau, or sea gypsies, were scouting for the Macassans-seeking out new areas for exchange and exploitation. Similarly Yolngu were also not privy to the political events in Southern Sulawesi in the 17th century, when the Dutch, in league with the Bugis, took Macassar by force and changed the nature of sea trade in the Indonesian archipelago for ever. What they did know was that Macassans were white and rich and Aborigines black and poor, and Aborigines had to work for the visitors to get what they wanted in the way of trade goods. Their autonomy was threatened, and it was the Warramiri leader Bukulatipi, who lived in the mid-1800s, who is credited with coming to a realisation about the nature of Birrinydji. His views, passed down through many hands and interpretive processes, are upheld as 'timeless' truths of the Dreaming.

Easy access to iron since the advent of the mission at Galiwin'ku in 1942 has resulted in a change of status for Birrinydji. As a foundational story for clans such as the Warramiri, can it simply vanish into obscurity? Following Sahlins, ${ }^{27}$ existing interpretations are seen to be put at risk by Burrumarra. Sahlins says that just as history is culturally ordered, so too are cultural schemes. Meanings are revalued as they are practically enacted. We take risks with our understandings, and as a result, culture is historically altered in action. Rudder ${ }^{28}$ has written about the changing nature of 'inside' accounts as new discoveries are made on the 'outside'. Everything that exists has an 'inside' equivalent, which may or may not have been revealed at a particular point of time, allowing the 'inside' to always appear to be unfolding before one's eyes. This was central to Burrumarra's understanding of the need for mining. Aboriginal history was suggestive of a potential that was yet to be realised, and he was testing the waters. Burrumarra believed the time was right for mining, but was uncertain of the extent of support for

26. Burrumarra pers. com. 1988. No Birrinydji sites were visited despite the fact that some coincide with trepang sites.

27. Sahlins 1981.

28. Rudder 1993. 
his interpretations of the significance of Birrinydji. Burrumarra's appeals to the Dreaming are based on a desire for an end to the poverty which for so long positioned Aborigines on the margins of non-Aboriginal society. The question is how, in giving his account of Birrinydji, does Burrumarra hope to make the future coincide with his vision of the past? And what becomes of Birrinydji in the process?

\section{Historical overview}

Published studies of the Macassan trepang industry do not correspond with what many older north-east Arnhem Landers say of the past. For instance some Yolngu posit waves of contact prior to the arrival of Macassans, yet historians like Macknight are adamant that this was not the case. In giving an overview of the Macassan trepang industry, Macknight says:

It began in about AD. 1700 and continued on until the early years of this century. For most of the nineteenth century, and probably the hundred years before that as well, at least a thousand men made the voyage each year...their product was exported to an international market. Their object was purely commercial, for they themselves had no use whatsoever for trepang. ${ }^{29}$

Aborigines were involved in diving for trepang, smoking and curing the sea slug, fishing, building smoke houses for curing, cutting firewood and digging wells. ${ }^{30}$ Not only were they wage labourers, they also stockpiled turtle shell, pearls and trepang and exchanged these for trade goods such as axes, knifes and tobacco. ${ }^{31}$ There was a degree of mutual trust between Aborigines and the visitors and certain Macassan boat captains had a basic knowledge of Aboriginal culture, languages and place names. ${ }^{32}$ The visitors had no interest in changing Aboriginal lifestyles or of exploring inland rivers for the purposes of colonization. ${ }^{33}$ By the late nineteenth century however there was a growing concern by Australian authorities about the trepang trade. The Macassans were not paying taxes and there were questions about their treatment of Aborigines. In 1907, after continued pressure for Europeans to take control of the industry, the Government prohibited the entry of these peoples, and a major chapter in Australian history came to an end. ${ }^{34}$

Yet for even the most casual observer of life in north-east Arnhem Land, it is apparent that for Aborigines this was not the end of the story. A significant number of Yolngu ceremonies are 'shot through' with Macassan references: ${ }^{35}$ healing rituals are held in honour of Allah; sand sculptures of boats lie alongside Aboriginal graves and bamboo flagpoles symbolic of Birrinydji are found in practically all communities. ${ }^{36}$

The most perplexing aspect of Aboriginal accounts of past encounters relate to the history and politics of skin colour. Told in the present, such stories are in accord with a

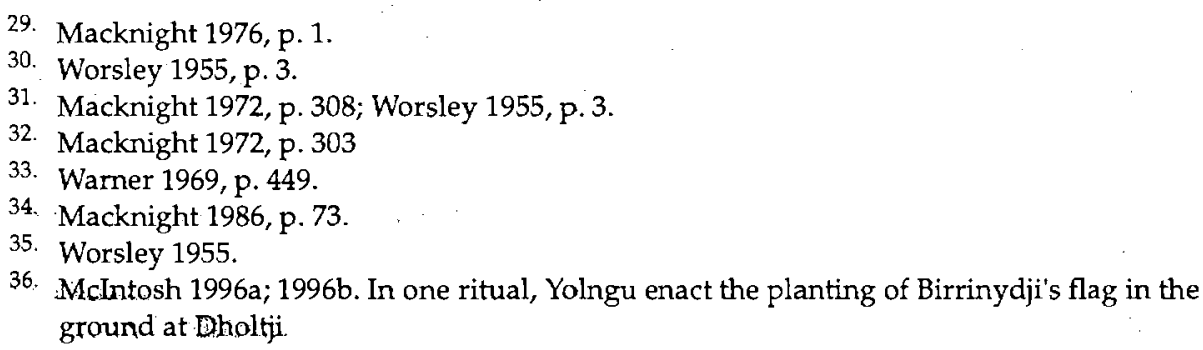


belief that at one time some Yolngu enjoyed an affluence and influence comparable to that of outsiders. Warramiri Yolngu say that the first visitors to the Arnhem Land coast were black, ${ }^{37}$ the next wave were golden-brown ${ }^{38}$ and then finally whites ${ }^{39}$ arrived. The pattern of contact correspondingly went from equality and reciprocity (the souls of dead Aborigines went to live in the homelands of the black voyagers); to a time when Aborigines and outsiders lived in harmony (they grew rice and made cloth and locally produced pottery and iron); to a time when trepangers, Japanese pearlers and then Europeans exploited and mistreated Aborigines.

Warramiri history, as relayed by Burrumarra, details how pre-Macassan voyagers would hunt for the whale along the Arnhem Land coast with their long spears, and then kill, carve and eat the beast following a pattern that was incorporated by Yolngu in ritual. Thus Burrumarra would say that Aborigines upheld the law of the whale, but they would use 'manikay, bilma and yidaki' (song, clapsticks and didjerido). Both Aborigines and outsiders were partners in maintaining the sacred order of the universe. With Macassans, the situation was similar but also different. Aborigines owned the ceremonies for iron and, as I describe later, they sing about the transformation of haematite into metal tools. However there is no corresponding sense of Aborigines and Macassans being united in a sacred partnership, though the Birrinydji stories infer that this was the case in the pre-Macassan era. As land owners and holders of this sacred law, Aborigines had the ability to transform 'red rock' or haematite. All their material needs were satisfied, for the Other worked for them.

\section{Iron use in north-east Arnhem Land}

There are no records of Aboriginal iron-making in pre-colonial Australia and similarly only scant references to the mythological significance of iron to Aboriginal populations in the early years of European settlement. Reynolds shows that some groups had terminology for the various products of the blacksmith's trade and had worked iron weapons while the metal was hot. ${ }^{40} \mathrm{He}$ also says that there was an early and widespread adoption of the use of iron by Aborigines following contact with Macassans though Warner suggests that the use of metal by Yolngu may have preceded the arrival of Indonesians. Wooden planks with nails attached would have been continually floating onto the coast from the north and north-west and might have been extracted and used as fish hooks. ${ }^{41}$

A major outcome of the Macassan period was an appreciation of iron's unique qualities and it became a highly prized item of trade. ${ }^{42}$ Particularly valued items were the tomahawk and knife, the detachable harpoon head, shovel-nose metal spear and the small metal bowl used in long wooden smoking pipes. According to Thomson, ${ }^{43}$ the Yolngu were good at working in metal, making fine spear heads by beating out cold odds and

\footnotetext{
37. Wurramala or whale hunters. See McIntosh 1995a; 1995c

38. The Bayini.

39. Macassans, Japanese and Europeans.

40. Reynolds 1990, p. 48.

41. Warner 1969, p. 450. Macknight, 1972, p. 304-305 says there is little evidence to support this view.

42. Warner 1969, p. 450; Macknight 1972, p. 305

43. Thomson 1949, p. 5; 1957, p. 31.
} 
ends of scrap metal and rigging screws, but there is no suggestion that such techniques were passed on as a result of contact with Indonesians. He writes:

[Aborigines]...made fish hooks and even knives from the nails and other fragments of iron that they salvaged from planks of driftwood, or iron from water tanks and trepang boilers of wrecked ships.

One of their most enterprising ventures in quest of iron occurred in Melville Bay where the Royal Air Force had anchored drums to serve as mooring buoys for...flying boats which had to refuel there. The [Aborigines], alive to the value of this iron within their reach, cut the drums adrift, beached them and cut them up into sheets of iron to be beaten into spears. ${ }^{44}$

Just as there are no records of Aborigines mining and smelting ironstone, there are no records of Macassans making metal tools on the Australian coast, although they definitely had an interest in prospecting. Earl was stationed at Port Essington in the early 1800 s and conducted a regular trade with the trepangers. He says that in the vicinity of Elcho Island and Arnhem Bay:

This part of the coast is apparently the termination of a granite range, and is said by the Macassars to abound in minerals, among which they mention tin, but... appears to me to be antimony-ore which will yield perhaps two-thirds of its weight in metal. ${ }^{45}$

Searcy traversed the coastline in the late 1800 s and he also mentions this interest by Macassans. At a trepang smoke house in Melville Bay he:

found specimens of quartz and ironstone, in one which a speck of gold could be distinctly seen...There was also a stack of manganese, which commodity for some reason the Malays [Macassans] took to Macassar. ${ }^{46}$

Elcho Island was also a source of 'red pigment' for the Macassans but their interest in this material is not clear. ${ }^{47}$ According to Burrumarra it could have been one of two types. Macknight ${ }^{48}$ says that Burrumarra had suggested this red clay was perhaps that which Aborigines collect from nearby Howard Island. Called Miku, it is dug out from a cleared area known as Gulpulu, burnt on the fire and then applied to the body in preparation for ceremonies. The alternative was the Dhuwa moiety red rock Rratjpa which is the source material associated with Yirritja moiety iron production. This red laterite is found in abundance in the cliffs at Galiwin'ku, Elcho Island, adjoining an old Macassan trepanging site. It is haematite (70\% iron), ${ }^{49}$ a variety of iron-ore used not only in the production of steel but commercially in the production of red paint.

Could Arnhem Land have been a source of raw material for local and overseas iron production? Macknight's detailed study of the Macassan trepang industry has shown that the visitors usually spent not more than a week or two in any location, but there are various recordings of visitors having to spend extended periods after being shipwrecked or failing to catch the trade winds in time for the return journey to

Thomson 1957, p. 31.

Earl 1842, p. 141

Macknight 1976, p. 44

47. See account of Daeng Sarro in Macknight 1979, p. 183.

48. Macknight fieldwork notes 1967.

49. Dana 1949, p. 484. 
Sulawesi. In normal circumstances however, as Macknight ${ }^{50}$ infers, it would be '...most unusual...during a voyage of this character'. Yet one could certainly imagine the types of situations where iron-making might have become a necessity say, for example, if the anchor was lost at sea or if nails were required to repair the praus and there were no other craft in the vicinity to lend assistance.

The process of iron manufacture does not require elaborate machinery. Any place where raw materials are available will suffice. In fact, techniques which might have been practised in Arnhem Land in the past are still carried on throughout eastern Indonesia today. As Reid says:

The characteristic Southeast Asian bellows-two vertical tubes with pistons lined with chicken-feathers, pumped by an apprentice sitting above them-is everywhere still in use. The remaining equipment is very basic-anvil, various hammers, a cutting wedge, tongs, scraper, and a bamboo full of water for tempering the steel. ${ }^{51}$

Harrisson and $O^{\prime}$ Connor describe the process in more detail. They write:

A furnace simply consisted of a sort of circular...pit, three or four feet in diameter, dug in compact earth...The pit was connected with a circular hole above,...through which the smelters subsequently added supplies of charcoal...After igniting the charcoal they closed the mouth of the pit by means of earth to keep back the heat and...to melt the ore. They then allowed the molten metal to flow out by tapping the lower part of the furnace and the slag was separated. $^{52}$

Macassans may well have made iron on the Arnhem Land coast and Aborigines of Burrumarra's clan either witnessed this or participated in its production. The many Aborigines who travelled to Macassar during the 200 years of the trepang trade would also undoubtedly have come across the industry. For instance Burrumarra, drawing his knowledge of the iron-making process from oral history and the songs of Birrinydji says:

Birrinydji used the 'red rock' from the beach, not bauxite, that's only for Gunapipi. ${ }^{53}$ [The red rock is] called Rratjpa... and comes from Djang'kawu [a Dhuwa moiety ancestral figure]. At Cape Wilberforce they call it Mirrki, red sand of the sunrise. Red rock is intelligence for all mankind, the source of wealth and power of Balanda and Yolngu-from it comes all the technology-axes, knives and hammers. ${ }^{54}$

While the 'red rock' is linked to Dhuwa moiety ancestral and totemic themes, Birrinydji is Yirritja. When the raw material is transformed by fire it enters a new domain separate from its former associations. Thus while in the Dhuwa moiety there are countless myths about Rratjpa, none is associated with iron production.

Details of iron-making are recorded not only in oral history and Yirritja mythology but also in art, song and in the personal names of Yirritja Yolngu. In the Warramiri

\footnotetext{
50. Macknight 1972, p. 309.

51. Reid 1983, p. 19.

52. Harrison \& O'Connor 1969, p. 313.

53. Sacred Dhuwa moiety ceremony.

54. Burrumarra pers. comm. 1988.
} 
clan alone, over $20 \%$ of the registered first names of clan members are drawn from the Birrinydji theme and in other coastal Yirritja clan groups, the figure is less but averages over $10 \% .{ }^{55}$ Cawte $^{56}$ details one song about knife manufacture in his book on the Warramiri. In this and related songs, the singer identifies himself with the technology of Birrinydji as well as the manufacturing process. It goes thus:

Ngayum djangu latimi

I am the blade

Ngayum djangu djidami

I am the handle

Ngayum djangu wambalmi

I am the long knife

Ngayum djangu butumi

I am the wood for a handle

Ngayum djangu rrawarra

I am the steel template.

Berndt also refers to Warramiri ceremonies associated iron-making. ${ }^{57} \mathrm{He}$ says the Gwolwunbuma, Lil'garun, Mararaguma, or Jandyaralguma, are connected with the shovel-nosed iron-bladed spear, the knife and the axe. Elkin likewise, in one of his Warramiri recordings from north-east Arnhem Land says that:

The song of the anvil describes vividly the darting of sparks and the 'cry' or resounding noise when the heated iron is struck with the hammer. ${ }^{58}$

Burrumarra says that all of these songs are from Birrinydji and are related generally to the idea of white and black men working together, for the legacy of this Dreaming being is centred on the concept of a partnership between peoples under the one law.

\section{The Birrinydji legacy}

In the 1940s, the Berndts found pottery fragments at a Macassan trepanging site at Port Bradshaw in north-east Arnhem Land. Aboriginal informants stated that such pots had been made by them from local ant hill in the pre-Macassan past. Songs recorded by the Berndts talk of this production. ${ }^{59}$ According to Aboriginal oral history, pottery making was a woman's job and it was the legacy of Birrinydji's wife, Bayini, to her historical female counterparts, both Aboriginal and non-Aboriginal. The same was the case for both cloth manufacture and weaving. Rice production, likewise, was carried out by Aboriginal women in Gumatj, Dhalwangu and Warramiri clan territories ${ }^{60}$ and informants can still point out the old paddy fields which today are usually associated with large fresh water billabongs. The rice has turned into rakay, the water chestnut, another significant Yirritja moiety totem. But there was and remains considerable variation in Aboriginal accounts of this 'pre-Macassan' period. As in the dog stories, they entail a

55. See Appendix.

56. Cawte 1993, p. 44.

57. Berndt 1949, p. 221.

58. Elkin 1953, p. 91.

59. Berndt \& Berndt 1947, p. 136. Subsequent analysis of the pottery fragments has not revealed their age, but has indicated that their origin was Indonesia, in all probability the Kai Islands of Maluku. See Key 1969.

60. Berndt and Berndt 1954, p. 37; Mountford 1956-64, p. 295. 
paradox. Stories stress Aboriginal wealth and self-sufficiency but also their subsequent loss in relation to outsiders. As the Berndts suggest, Aborigines did not desire to imitate the Bayini, preferring their own way of life and while the two groups co-existed, they did not seem to be willing to learn from each other. The Bayini, they say, kept the secret of weaving to themselves. ${ }^{61}$

In contrast to the occupations and technologies of the female ancestral being Bayini, the mining and smelting of iron-ore was work for men, and Birrinydji, the 'man of iron', instructed Aborigines in this trade. According to Yolngu, references to the making of iron are thus wrongly attributed to the Macassan era. They say it was in the 'preMacassan' or Murrnginy ${ }^{62}$ period, the 'golden age' of Birrinydji. According to Burrumarra:

Macassans had Birrinydji in common with Arnhem Land but the spirit of Birrinydji is Dholtji. All things came to the Warramiri from Birrinydji and then to other clans.

While some of Burrumarra's interpretations regarding Birrinydji may be of recent origin, there are oblique references to this Dreaming figure going back to the first recorded anthropological interviews with Yolngu in the $1920 \mathrm{~s} .{ }^{63}$ More recently Cawte ${ }^{64}$ described Warramiri bark paintings showing Birrinydji at work by his furnace. In a perspective drawn from a region some hundreds of kilometres to the south-west of Elcho Island, MacInolty and Wainburranga describe Birrinydji as 'Captain Cook'. They write:

Captain Cook was a Yirritja man...All these people from the Rembarrnga side, from Warramiri side, Gupapuyngu, [Golpa], Dhalwangu, Balamumu, Gumatj...have a corroboree for him... When Captain Cook died Yirritja people took it over. My mob...took over his song too. They call it barrambarra...material stuff, blankets, calico. All the sort of stuff we have-it's got a song...He was very kind to Aboriginal people in the early, early days...He didn't interfere. He knew not to interfere...People know he had white man's power, white man's things. He came to the good law. But when the new Captain Cook's came over-bad things happened. They started shooting people then. New Captain Cook people... They are the ones who have been stealing all the women and killing people. They have made war...They wanted to take all of Australia. ${ }^{65}$

While MacInolty and Wainburranga are referring to the impact of European colonists in Australia and there is no mention of Macassans, the parallel to the way Yolngu speak of waves of contact is immediately apparent. Indeed, as the Berndts record, while the Macassans appear to have been welcomed initially, relations deteriorated in the last phase of contact in the late 1800s. They say, 'In the old days...trading partnerships were established between the two groups. These involved reciprocal obligations and created classificatory ties of kinship. ${ }^{66}$ In the final stages of the industry, '...the Aborigines began to feel that they were being exploited' ${ }^{67}$ Alcohol was introduced as a means of

61. Berndt and Berndt 1954, p. 38.

62. Murrnginy or Murngin, was the word that Warner 1969 used to refer to Yolngu. It means 'the iron age of Birrinydji' according to Burrumarra.

63. Warner 1932; 1969 .

64. Cawte 1993, p. 42-46.

65. MacInolty \& Wainburranga,1988, p. 356-359.

66. Berndt \& Berndt 1954, p. 47. 
paying Aborigines leading to violence on both sides. It led to prostitution in the Macassan camps and the death of many Aborigines by gun or sword. ${ }^{68}$ There were many murders of crew members as well. The atrocities described by Searcy ${ }^{69}$ are linked to this time.

Comparing MacInolty and Wainburranga's account with the views of Burrumarra is equally enlightening. Burrumarra said that there are one Birrinydji and five Bayini, one for each of the Yirritja clans linked to this law. All Warramiri are descended from Birrinydji and Bayini. He said:

Birrinydji and Bayini are for Dholtji. All things come from Birrinydji. Two thousand years ago people came to our land. They had a job to do. They wanted to make the land and the people strong. It was at Birrinydji's command that they came. The iron in the ground acted like a magnet, drawing them in. Birrinydji was like a blanket over the land. Everything came under him. He was both 'white' and 'black'. He was very rich and had many things. He was an iron-maker. Bayini made clothing, planted rice and directed Yolngu women in this. Birrinydji came from the ground, from the gold beneath. Visitors to Dholtji had settlements all along Cape Wilberforce. There were thousands of people, men, women and children...When we followed Birrinydji's law, we prospered. But then things started to go wrong. We wanted only good but bad came too... We turned our back on the laws of Birrinydji and we lost everything. There is great sadness in our memory and this is why we don't like to bring it up. Today we follow the laws of Birrinydji. We have only the song and the ceremony but we have lost the ability to make iron. But if we follow this law, maybe these things will come to us again. 70

Aboriginal people as far away as Groote Eylandt and Western Australia knew of Birrinydji, Burrumarra believed. They referred to him as 'Captain Cook', Balanda, Ngapagi, Munanga, Wurupanda or Wurubalanda. ${ }^{71}$

The stories of 'Cook' and Birrinydji deal with the sacred 'inside' meaning and origin of those items introduced by Macassans and Europeans and also the consequences of encroachment and exploitation. The Dog stories throw considerable light on the predicament of Aborigines, for as stated, these narratives are outside versions of this same story of loss. In Yolngu cosmology there are two sets of dogs. ${ }^{72}$ The ones who live with people as pets and are given skin names, personal names and considered almost as family members, are referred to as Wunggan or Waatu. Then there are the wild dogs, whose names Warrang or Wakinggu mean literally 'having nothing and belonging to no-one'. These are terms of abuse used by Aborigines, for to be wakinggu is to be without kin and without skin. As Kolig and Rose describe, ${ }^{73}$ the characteristics of the dingo are used by Aborigines as a measure of how humans should behave. Yolngu do not kill for pleasure, share what they have and eat only what they need. They do not mate indiscriminately but live according to complex social laws. In other words, by putting

67. Berndt \& Berndt 1954, p. 110.

68. Berndt \& Berndt 1954, p. 47.

69. Searcy $1909 ; 1912$.

70. Burrumarra quoted in McIntosh 1992, p. 101.

71. All of these terms refer to the 'whiteman' ie. Europeans and Macassans.

72. McIntosh 1992; 1994a.

73. Kolig 1978; Rose 1992. Kolig's work was in the Kimberly, and Rose in the Victoria River district. 
themselves in the place of the dingo in myths of first contact, Yolngu are making a statement about their own anti-sociability, impoverishment and potential dependency upon the Other. They are one with the visitors, as the pet dog is to Aborigines, but they do not live according to the social laws which the visitors once upheld and wished to share; i.e. the laws of the first 'Cook' that some Yolngu label 'Birrinydji'. At one time Aborigines prospered and lived the good life, but now the myths suggest that they live as dogs baying at the heels of the Other, and this is to be resisted at all costs. Human beings should not act this way.

Contact history has created two types of people in Warramiri cosmology-Yolngu (and other black-skinned peoples) and Balanda. Yolngu possess the songs and dances for Birrinydji but, because of the dog, are powerless to alter their status except by appeal to the Dreaming. Balanda have the technology necessary to extract and transform haematite into abstract wealth, but they can never totally dominate Yolngu because Birrinydji is an Aboriginal law.

While the visitors initially wanted to share their wealth, Aborigines rejected them, and later voyagers did not respect Yolngu rights (i.e. the new 'Captain Cooks'). As time went by, non-Aborigines got richer and whiter and more and more ignorant of the law, and Yolngu got poorer and blacker and, according to Burrumarra, the dances of Birrinydji became more and more popular. When gifts were presented by Macassans to Aborigines in trade, which often occurred at the end of the season, ${ }^{74}$ Aborigines would hold great ceremonies on the beaches honouring Birrinydji, not the visitors, for it was an acknowledgment of the partnership that once was, and must be again in the future. ${ }^{75}$ As in Burrumarra's dream, the desire was and still is to be able to have all the benefits of the Balanda way of life without losing one's identity as an Aborigine or control of one's land.

\section{The dilemma of mining}

Stanner ${ }^{76}$ says that for Aborigines the present is determined by the past. There is a complete subordination of history to the ideology of the Dreaming. Burrumarra would have agreed. To follow the law and realise a pre-ordained future, mining must occur, but only on Aboriginal terms. But then there is the legacy of other creational figures such as Lany'tjun, the founder of the Yirritja moiety. Each Yirritja Yolngu clan was ascribed certain territories by Lany'tjun to care for, at the 'beginning of time'. So there is a tension here, and this was evident in Burrumarra's dream. For many Yolngu mining is not an option and the very idea of non-Aboriginal companies drilling on Yolngu land evokes a deep bitterness, especially in the Gove area. Some see Birrinydji, and consequently their Aboriginality, as being vulnerable to such desecration. For example when satellite mining exploration photos were taken in the Gapuwiyak area in the late 1980s, without Aboriginal consent, Birrinydji was seen in the shadows running from the camera. ${ }^{77}$ This

\footnotetext{
74. Berndt \& Berndt 1954, p. 46.

75. Burrumarra pers. com. 1992; McIntosh 1995c. This same ceremony was performed during a visit by the Governor-General to Elcho Island in 1988.

76. Stanner 1984.

77. Yepaynga pers. comm. 1988.
} 
fear of mining by Yolngu is well documented. In relation to a painting of Birrinydji with the metal tools of his trade, Cawte says:

Warramiri contemplating Birrinydji are supposed to ponder why their 'iron age' was lost... Does an iron age destroy itself because mining violates the earth? ${ }^{78}$

In the case of Bol'lili's and Djuranydjura's encounters with Macassans, the dogs appear to accept their fate as being poor and subservient to whites. Yet in other versions of these narratives, the encounters provide motivation for social action designed to reverse an undesirable situation. Rose for instance says that Aborigines believe that by making public the atrocities perpetrated by 'Cook', changes in the laws defining relationships between Aborigines and non-Aborigines will result. ${ }^{79}$

While Burrumarra linked the extraction of bauxite and the production of alumina at the Nabalco plant at Gove with Birrinydji's iron-making, he was against the mine from the outset because of a failure on the part of developers to consult with Yolngu. Yet as far back as the 1950s, Burrumarra and other Yolngu leaders had tried to negotiate mining deals for the extraction of bauxite from the Wessel Islands. In the plan that was envisaged ${ }^{80}$ Aborigines would have a controlling interest in the project and there was a guarantee that no sacred sites would be interfered with. The negotiations entered into with missionaries and others predated by over twenty years the Aboriginal Land Rights Act and the powers it grants Aborigines.

The Warramiri leader was also involved in discussions leading to the establishment of land councils in the Northern Territory. For him, such representative bodies are, in part, the realisation of Birrinydji's plan for Yolngu. Here was a body funded by nonAborigines whose charter was to act in ways conducive to Aboriginal interests, hinting at the time when both whites and blacks were followers of the one law. The implication of course is that Birrinydji only exists so long as there are divisions in material wellbeing between cultural groups. From Burrumarra's perspective, mining should be allowed on Aboriginal land but only as long as Balanda respect Yolngu wishes, listen to the land owners and share equally in all proceeds. Many Yolngu make their decision on mining on the basis of this Dreaming precept.

In the Northern Territory, the Aboriginal Land Rights Act (NT) gives Aborigines the power of veto over development. In the case of mining exploration at Dholtji in 1988, while Burrumarra's dream did not change his feelings on pushing ahead with the project, his family marked off so much of the exploration zone as sacred and 'no go' areas that it was not feasible for the company to proceed. In 1996, two years after Burrumarra's death, the present day leader of the Warramiri, Wulukang, said 'no' to mining even though a majority of Burrumarra's family were now in favour of opening up their land. The country was too sacred.

In an ideal world, support for development projects on indigenous land would come from indigenous people themselves. They would have a comprehensive understanding of any potential impacts and as a group delineate areas of land suitable for an agreed project from within their territories. With the support of other potentially

78. Cawte 1993, p. 68.

79. Rose 1984.

80. While it attracted the interest of several companies, it did not proceed. 
affected indigenous peoples, they would embark on a project or negotiate directly with companies of their choice. They would enter into contracts as equal partners, be employed in the ventures, and monitor progress through to completion and rehabilitation of the land. In the real world however, indigenous people contemplating development are forced into a position where they must think about the contemporary nature of their identity as Aborigines and their marginalisation as a community in relation to non-Aborigines. I have often heard it said that if a company demonstrates a willingness to get to know the people, comes to an understanding of the struggles they are engaged in, and are willing to share in the wealth that will be generated by doing business on Aboriginal land, then a 'yes' answer will not be uncommon for access to Aboriginal land.

For a range of reasons, many connected to his own family history, Burrumarra's answer for his own country was always 'yes', though the history of race relations in north-east Arnhem Land worked against his wish. The people, as a whole, usually say 'no'. Past and bitter experience with mining companies, as well as damage to sacred sites, environmental pollution, and the social impacts of royalty payments, all weigh heavily on people's minds when mining decisions are being made. But at the very least, the 'fact' of iron-making on remote Arnhem Land beaches provides an alternative to the sharply contrasting views that to say 'yes' to mining means selling out one's inheritance (as when Birrinydji went into the ground), while saying 'no' results in the maintenance of cultural difference and poverty (as with Djuranydjura). For Burrumarra, mining on Aboriginal terms would mean one could be wealthy and simultaneously maintain one's sense of identity and power. To him, this was the legacy of Birrinydji.

\section{Conclusion}

The sequence of events in time implicit in an 'inside' reading of the Macassan past can be interpreted as providing guidelines for attaining a desired future, progressively, in the here and now. The essential ingredients are the rebuilding of ties of reciprocity, and respect for land and sea rights. Bakhtin ${ }^{81}$ speaks of such a perspective as historical inversion. History is something yet to be achieved. Myths about paradise, a golden or heroic age, or an ancient truth which are in no way a part of the past, can only be realised in the future. Oral traditions relating to Birrinydji represent a potential, a dream of how things should be if the law is followed. In the scenario presented here, Burrumarra brings to the fore a perspective on the past which is considered anachronistic by many. Burrumarra professed certainty, but his dream indicated otherwise. Aborigines throughout the Arnhem Land region no longer believe that the technology of whites comes from an Aboriginal Dreaming and that in order to enjoy material prosperity, one has to follow the law of Birrinydji and hence go through clans such as the Warramiri to obtain highly prized items of trade. The significance of Birrinydji is being revalued, but to what end? Proclamations by Burrumarra on Birrinydji reflect the group leader's conceptions of Warramiri social identity-where they have come from and where they should be going as a people. Warramiri history is an ideology that links Aborigines, Macassans and other non-Aborigines, and provides a commentary on present day lifestyles and the status of relationships. Rather than a passive device for classifying histor- 
ical events, the Birrinydji narrative is a program for orienting social, political, ritual, and other forms of historical action. ${ }^{82}$ For Burrumarra, the proclamation of the Land Rights Act and the growing influence and affluence of Aborigines in Australia has created the circumstances whereby mining can and should occur. That the two go together-a social environment of reconciliation and the willingness of mining companies to enter into negotiations with Yolngu-is seen to be a part of Birrinydji's plan. It is the realisation of the Dreaming in the here and now. History will have achieved its potential.

\section{Appendix}

Balandad-engineer or iron worker.

Banul-'exhaust' pipe for smoke emission.

Banuwanu-handle for a knife.

Batingarra-Birrinydji's iron worker. He makes knives and swords and puts handles on them.

Batiti-knife maker.

Birrarrapi-the iron furnace of Birrinydji.

Bongguna-a lead or iron chest.

Damung-iron of Birrinydji.

Dhatu-chimney.

Djarrimili-iron.

Djimbuluku—an iron post.

Duwarriny-smoke from a large chimney or furnace, like at Gove.

Guthadjaka-iron worker.

Lalanbarri-copper or iron.

Lalanggutha-iron.

Lati-knife.

Layipu-iron cooking pots of Bayini.

Mulung-knife.

Munbirrngu-iron worker in the image of Birrinydji.

Nepa-knife.

Rrawara-large knife or sword/steel template.

82. Turner 1988 , p. 23. 


\section{References}

Bakhtin, M.M. 1981. Forms of Time and of the Chronotype in the Novel. Notes toward a Historical Poetics. In M. Holquist (ed) The Dialogic Imagination. Four Essays by M.M. Bakhtin. University of Texas Press, Austin, pp. 84-258.

Beckett, J. 1993. Walter Newton's history of the world-or Australia. American Ethnologist 20(4):675-695.

Berndt, R. M. \& Berndt, C. H. 1947. Discovery of pottery in north-eastern Arnhem Land. Journal of the Royal Anthropological Institute, London, 77:133-140.

Berndt, R.M. 1948. Badu, islands of the spirits. Oceania, 19(2):94-103.

Berndt, R.M. \& Berndt, C.H. 1949. Secular figures of northeastern Arnhem Land. American Anthropologist, 51(2):213-222.

Berndt, Ronald M. \& Berndt Catherine H. 1954. Arnhem Land. Its History and Its People. F.W. Cheshire. Melbourne.

Berndt, R.M. 1978/79. Looking back into the present: a changing panorama in eastern Arnhem Land. Anthropological Forum 4(1), 281-296.

Bloch, M. 1977. The past and the present in the present. Man 12:278-292.

Cawte, J. 1993. The Universe of the Warramirri. Art, Medicine and Religion in Arnhem Land. University of New South Wales, Sydney.

Dana, E.S. 1949. A Textbook of Mineralogy, with an Extended Treatise on Crystallography and Physical Mineralogy. Fourth Edition. John Wiley \& Sons, New York.

Earl, G.W. 1842. Notes on northern Australia and the neighbouring seas. Journal of the Royal Geographical Society of London. 12:139-141.

Elkin, A.P. 1953. Arnhem Land music. Oceania 24(2):81-109.

Flinders, M. 1814. A Voyage to Terra Australis. G. and W. Nichol, London.

Harrisson, T. \& O'Connor, J. 1969. Delta iron in a southeast Asian context. Excavations of a Prehistoric Iron Industry in West Borneo. Vol. 2. Associated Artifacts and Ideas. Data Paper No.72. South East Asia Program, Cornell University, Ithaca, New York.

Keen, I. 1994. Knowledge and Secrecy in an Aboriginal Religion. Yolngu of North-East Arnhem Land. Clarendon Press, Oxford.

Key, C.A. 1969. Archaeological pottery in Arnhem Land. Archaeology and Physical Anthropology in Oceania, 4:103-106.

Kolig, E. 1978. Aboriginal dogmatics: canines in theory, myth and dogma. Bijdragen tot de Taal-, Land-en Volkenkunde 134:84-115.

Macknight, C.C. 1972. Macassans and Aborigines. Oceania. Vol. 42(4):283-321.

Macknight, C.C. 1976. The Voyage to Marege. Macassan Trepangers in Northern Australia. Melbourne University Press, Melbourne.

Macknight, C.C. 1979 (ed). The Farthest Coast. A Selection of Writings Relating to the History of the Northern Coast of Australia. Melbourne University Press, Carlton.

Macknight, C.C. 1986. Macassans and the Aboriginal past. Archaeology in Oceania 21:6975.

MacInolty, C. \& Wainburranga, P. 1988. Too many Captain Cooks. In T. Swain and Rose, D.B. (eds), Aboriginal Australians and Christian Missions: Ethnographic and Historical 
Studies. Australian Association for the Study of Religions, Bedford Park, pp. 355360 .

McIntosh, I.S. 1992. The Bricoleur at Work: Warang (Dingo) Mythology in the Yirritja Moiety of North-east Arnhem Land. Master of Letters Thesis, University of New England.

McIntosh, I.S. 1994a. The dog and the myth maker. Macassans and Aborigines in northeast Arnhem Land. Australian Folklore 9:77-81.

McIntosh, Ian 1994b. The Whale and the Cross. Conversations with David Burrumarra, M.B.E. Northern Territory Historical Society, Darwin.

McIntosh, I.S. 1995a. Maluku 'totem' hunters and Sama-Bajau in north Australian Aboriginal mythology? Aboriginal Folklore 10:50-60.

McIntosh, I.S. 1995b. Who are the Bayini? The Beagle. Records of the Museums and Art Galleries of the Northern Territory, 12:193-208.

McIntosh, I.S. 1995c. Yolngu sea rights in Manbuynga ga Rulyapa (Arafura Sea) and the Indonesian connection. In J. Finlayson and D.E. Smith (eds) Native Title: Emerging Issues for Research, Policy and Practice. Research Monograph No.10. Centre for Aboriginal Economic Policy Research, Australian National University, Canberra, pp. 9-22

McIntosh, I.S. 1996a. Can we be equal in your eyes? A perspective on reconciliation from Yolngu myth and history. PhD thesis, Northern Territory University, Darwin.

McIntosh, I.S. 1996b. Islam and Australia's Aborigines? A Perspective from North-east Arnhem Land. Journal of Religious History 20(1):53-77.

Morphy H. and Morphy, F. 1984. The 'myths' of Ngalakan history: ideology and images of the past in northern Australia. Man 19(3):459-478.

Mountford, C.P. 1956-64. Records of the American Australian Scientific Expedition to Arnhem Land. Volume One. Art, Myth, and Symbolism. Melbourne University Press, Melbourne.

Reid, A. 1983. The Rise of Macassar. Rima 17:117-160.

Reynolds, H. 1990. The Other Side of the Frontier. Penguin, Melbourne.

Rose, D.B. 1984. The saga of Captain Cook: Morality in Aboriginal and European Law. Australian Aboriginal Studies 2:24-39.

Rose, D.B. 1992. Dingo Makes Us Human: Life and Land in an Australian Aboriginal Culture. Cambridge University Press, Melbourne.

Sahlins, M. 1981. Historical Metaphors and Mythical Realities: Structure in the early history of the Sandwich Islands Kingdoms. Association for the Study of Anthropology in Oceania, Special Publication No.1, Ann Arbor: University of Michigan, Michigan.

Searcy, A. 1909. In Australian Tropics. Second Edition. George Robinson and Co., London.

Searcy, A. 1911. By Flood and Field. Adventures Ashore and Afloat in North Australia. G. Bell and Sons, Ltd., London.

Stanner, W.E.H. 1984. Religion, totemism and symbolism. In M. Charlesworth, H. Morphy, D. Bell and K. Maddock (eds), Religion in Aboriginal Australia. University of Queensland Press, Brisbane, pp. 137-172.

Thomson, D.F. 1949. Economic Structure and the Ceremonial Exchange Cycle in Arnhem Land. Macmillan, Melbourne. 
Thomson, D.F. 1957. Early Macassar visitors to Arnhem Land and their influence on its people. Walkabout, 23(7):29-31.

Turner, T. 1988. Ethno-ethnohistory: myth and history in native South American representations of contact with western society. In J.D. Hill (ed) Rethinking History and Myth. Indigenous South American Perspectives on the Past, 235-281. University of Illinois Press, Chicago.

Warner, W.L. 1932. Malay influence on the Aboriginal cultures of north Australia, Oceania 2(4):476-495.

Warner, W.L. 1958/69. A Black Civilization. A Social Study of an Australian Tribe. Harper \& Roe, Chicago.

Worsley, P.M. 1955. Early Asian contacts with Australia. Past and Present 7:1-11. 